Ann. Biol. anim. Bioch. Biophys., 1978, 18 (4), 997-1000.

\title{
The effect of storage conditions on the biological activity of salmon gonadotropin
}

\author{
par E. M. DONALDSON, Helen M. DYE, B. F. WRIGHT \\ Nutrition and Applied Endocrinology Program, Resource Services Branch, \\ Fisheries and Marine Service, 4160 Marine Drive, West Vancouver, B. C. Canada V7V 1 N6.
}

Summary. The purpose of this study was to determine the effect of environmental conditions on the biological activity of salmon gonadotropin (SG-G100) during storage. At low relative humidity $(\mathrm{RH})$ there was no significant loss or gain in gonadotropic activity at $35^{\circ} \mathrm{C}$ or $50^{\circ} \mathrm{C}$ over 21 days. At high RH there was a significant loss of potency at $35^{\circ} \mathrm{C}$ after 10 and 21 days while at $50^{\circ} \mathrm{C}$ after 21 days, there was almost complete loss of activity. When SG-G100 was held in saline for 7 or 21 days, there was a significant loss of activity at $20-25^{\circ} \mathrm{C}$ after 7 days and at $90^{\circ} \mathrm{C}$ after 21 days. In the second phase SG-G100 was held for 2, 4, 6 and 16 months at $35^{\circ} \mathrm{C}$ and low $\mathrm{RH}$, prior to bioassay. Activity was maintained for 6 months but by 16 months had declined relative to gonadotropin held at $-40^{\circ} \mathrm{C}$.

\section{Introduction.}

Partially purified salmon gonadotropin SG-G100 (Donaldson et al., 1972) has been used in reproductive studies on several species of fish (Donaldson, 1973) however, to date, no investigation has been made of its biophysical properties with regard to shipping and storage. This study was undertaken to facilitate a project in Malaysia on the spawning of chinese carps for the purpose of fry production. The experiments were designed to determine the effect of transportation and storage of the hormone at high ambient temperatures and low and high humidity. In addition an experiment was carried out to establish whether the gonadotropin could be kept in saline solution for several days without deterioration.

\section{Material and methods.}

Treatment of gonadotropin samples. - The gonadotropin used in this study was partially purified chum salmon (Oncorhynchus keta) gonadotropin, SG-G100, prepared in this laboratory for the International Development Research Center. The study was conducted in two phases. In the first phase the effect of storing the SG-G100 at low and high humidity for 3-21 days and in solution for 7-21 days was investigated. In the second phase the effect of storing the SG-G100 af low humidity at $35^{\circ} \mathrm{C}$ for 2 to 16 months was investigated. 
In phase 1 the conditions of humidity and temperature were obtained by placing the samples in a covered water bath (Grant Instruments, Cambridge Type SSB4). The flasks containing the high humidity samples were open to the atmosphere of the incubator via an inverted « $U$ » tube while the low humidity samples were sealed in flasks containing silica gel desiccant. Samples stored in solution were dissolved in 0.85 p. 100 $\mathrm{NaCl}, 0.1$ p. 100 bovine serum albumin at concentrations of 125 and $250 \mu \mathrm{g} / \mathrm{ml}$ and stored either in a refrigerator at $9{ }^{\circ} \mathrm{C}$ or at room temperature $\left(20-25^{\circ} \mathrm{C}\right)$. In the second phase the closed vials of SG-G100 were placed in a beaker containing silica gel which was covered with «Parafilm » and placed in Blue M Model 100A incubator oven at $35^{\circ} \mathrm{C}$.

Bioassay. - Relative potencies of the treated SG-G100 samples were determined using the augmentation of radiophosphate $\left({ }^{33 P}\right)$ uptake by the chick testis (Florsheim et al., 1959 ; Breneman ef al., 1962 ; Follett and Farner, 1966 ; Donaldson et al., 1972). Control (untreated) SG-G100 was stored at $-40^{\circ} \mathrm{C}$ prior to assay. Dosages of treated and untreated SG-G100 ranged from 6.25 to $50 \mathrm{\mu g} /$ chick. Computer analysis was of a completely randomized four-point design. Analysis of variance tested parallelism, regression and preparation. The computer program also tested for the significance of the difference between potency ratios.

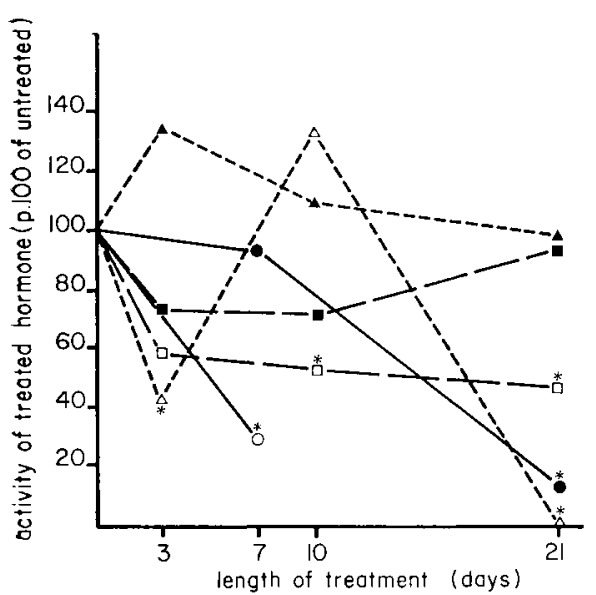

FIG. 1.

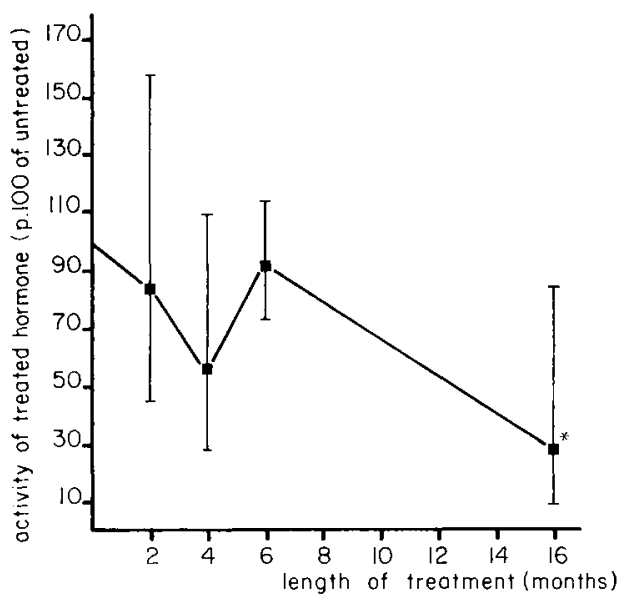

FIG. 2.

FIG. 1. - Effect of storage for 3-21 days at $35^{\circ} \mathrm{C}$ and $50^{\circ} \mathrm{C}$ at low and high humidity and in solution at $9^{\circ} \mathrm{C}$ and $20-25^{\circ} \mathrm{C}$ on the gonadotropic pofency of solmon gonadotropin SG-G100. Potencies are expressed as a percentage of the potency of control SG-G 100 held at $-40^{\circ} \mathrm{C}$. Asterisks indicate potencies that were significantly different from the control $(P<0.05)$.

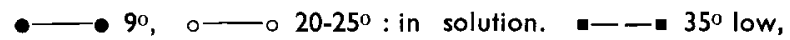

$$
\begin{aligned}
& \text { 口- - } 35^{\circ} \text { high, } \Delta \cdots-\cdots 50^{\circ} \text { low, } \Delta \cdots-\cdots 50^{\circ} \text { high : relative humidity. }
\end{aligned}
$$

FIG. 2. - Effect of storage for 2-16 months af $35^{\circ} \mathrm{C}$ and low humidity on the gonadotropic potency of salmon gonodotropin SG-G100. Potencies expressed as a percentage of the potency of control SG-G100 held at $-40: C$. Asterisk indicates a potency that was significantly different from the control $(P<0.05)$. 
Indices of precision for the various bioassays ranged from 0.19 to 0.39 in the first phase and from 0.15 to 0.34 in the second phase. The potencies of the salmon gonadotropin stored under various conditions have been expressed as a percentage of the potency of salmon gonadotropin stored at $-40^{\circ} \mathrm{C}$.

\section{Results.}

The results for the first phase of the experiment which involved storage for 3-21 days are shown in figure 1. The results for the second phase of the experiment which involved storage for 2 to 16 months are shown in figure 2 . No significant changes in potency occurred when SG-G100 was stored at $35^{\circ} \mathrm{C}$ or $50^{\circ} \mathrm{C}$ for 21 days at low humidity. Storage at high humidity on the other hand resulted in a significant loss of potency after 10 and 21 days at $35^{\circ} \mathrm{C}$ and after 3 and 21 days at $50^{\circ} \mathrm{C}$. In fact there was virtually no gonadotropic activity in the latter sample (fig. 1). Storage in solution at $9{ }^{\circ} \mathrm{C}$ for 7 days resulted in no significant loss of potency while storage in solution at $9^{\circ} \mathrm{C}$ for 21 days or $20-25^{\circ} \mathrm{C}$ for 7 days resulted in significant loss of potency. Untreated SG-G100 minus albumen had the same potency as untreated SG-G100 with albumen, suggesting that albumen is unimportant in the injection solution. In the second phase storage for 2, 4 and 6 months at $35^{\circ} \mathrm{C}$ in a low humidity atmosphere resulted in no significant loss in activity while storage for 16 months resulted in a significant loss to approximately one quarter of the original potency (fig. 2).

\section{Discussion.}

This investigation is probably the first systematic storage study which has been conducted on a lower vertebrate gonadotropin preparation. While the general trend of the findings confirmed our expectations, it would not have been possible to determine safe storage times in the dry state and in solution without conducting the study.

Storage of salmon gonadotropin in a warm humid atmosphere for even a short period of time resulted in rapid loss of gonadotropic potency. Storage in a warm dry atmosphere on the other hand did not lead to a significant deterioration in potency during short and medium term storage. This finding permits the shipping of salmon gonadotropin at ambient temperature to tropical regions of the world providing that suifable precautions are taken to ensure an environment of low humidity. In this laboratory this is accomplished by placing the SG-G100 in plastic stoppered glass vials and placing the vials in a vapour proof polyester film pouch, containing silica gel desiccant, which is then heat sealed.

Most investigators prefer to prepare injection solutions on the day they are to be used, however, our data indicate that when necessary SG-G100 can be stored in saline solution without significant loss of activity for 7 days providing that it is held at $9{ }^{\circ} \mathrm{C}$ or below.

While SG-G100 can be shipped and stored at $35^{\circ} \mathrm{C}$ for up to 6 months without significant loss of biological activity, losses did occur by 16 months. Thus long term storage is best accomplished by placing the hormone in suitable containers in the freezer. While we prefer $-40^{\circ} \mathrm{C}$ for extended storage $-20^{\circ} \mathrm{C}$ is probably adequate for 
most purposes. When a vial containing SG-G100 is removed from the freezer it is allowed to stand until it reaches room temperature before being opened to prevent atmospheric water condensing upon the contents.

\section{Conclusions.}

Salmon gonadotropin can be shipped at ambient temperature providing it is in a low humidity atmosphere. Long term storage is preferably conducted in a low temperature freezer. When necessary SG-G100 may be stored in saline solution for up to one week in a refrigerator.

Symposium sur la Reproduction des Poissons Paimpont, France, 19-21 sepfembre 1977.

Acknowledgments. - The authors wish to express their gratitude to the International Development Research Centre for funding the first phase of the project (3P730069 Gonadotropin UBC). We wish to thank Drs. W. H. L. Allsopp and B. Davy for constructive discussions during the course of the project; $\mathrm{Mr}$. G. Hunter for able assistance with the chick bioassays; Mr. J. H. Bjerring for computer processing of the data and Mrs. M. Young for typing the manuscript.

Résumé. Nous avons étudié l'effet des conditions de stockage sur l'activité biologique de la gonadotropine de saumon (SG-G100). Quand l'humidité relative (RH) est faible, l'activité gonadotrope reste stable à $35^{\circ} \mathrm{C}$ ou $50^{\circ} \mathrm{C}$ pendant plus de 21 jours. Quand l'humidité relative est élevée, l'activité baisse significativement à $35^{\circ} \mathrm{C}$ après 10 et 21 jours, tand is qu'à $50^{\circ} \mathrm{C}$ la perte d'activité est à peu près totale après 21 jours. Quand la gonadotropine est conservée dans une solution saline pendant 7 ou 21 jours, la perte d'activité est significative à 20-25 ${ }^{\circ} \mathrm{C}$ après 7 jours et à $9^{\circ} \mathrm{C}$ après 21 jours.

Durant le stockage sur une période prolongée de 2, 4, 6 ou 16 mois, l'activité biologique est maintenue jusqu'à 6 mois à $35^{\circ} \mathrm{C}$ en humidité relative faible, et pendant 16 mois à une température de conservation de $-40^{\circ} \mathrm{C}$.

\section{References}

BRENEMAN W. R., ZELLER F. J., CREEK, R. O., 1962. Radioactive phosphorus uptake by chick testis as an end point for gonadotropic assay. Endocrinology, 71, 790-798.

DONALDSON E. M., 1973. Reproductive endocrinology of fishes. Am. Soc. Zool. Symp. The current stotus of fish endocrine systems. Am. Zool., 13, 909-927.

DONALDSON E. M., YAMAZAKI F., DYE H. M., PHILLEOW.W., 1972. Preparation of gonadotropin from salmon (Oncorhynchus tshawytscha) pituitary glands. Gen. comp. Endocr., 18, 469-481.

FLORSHEIM W. H., VELCOFF S. M., BODFISH R. E., 1959. Gonadotropin assay based on augmentation of radiophosphate uptake by the chick testis. Acta endocrinol., 30, 175-182.

FOLLETT B. K., FARNER D. S., 1966. Pituitary gonadotropins in the Japanese quail during photoperiodically induced gonadal growth. Gen. comp. Endocr., 7, 125-131. 